\title{
Clinical profile and risk factors for mortality among COVID-19 in patients at a tertiary care centre in Bengaluru, India
}

\author{
Yamini Marimuthu $^{1}$, Radhika Kunnavil ${ }^{1}$, NS Anil ${ }^{1}$, Sharath Burugina Nagaraja ${ }^{1}$, N Satyanarana ${ }^{2}$, \\ Jeetendra Kumar ${ }^{3}$, Bojja Ramya ${ }^{3}$ \\ ${ }^{1}$ Department of Community Medicine; ${ }^{2}$ Department of General Medicine, ESIC Medical College and Post Graduate \\ Institute of Medical Sciences and Research, Rajajinagar, Bengaluru; ${ }^{3}$ ESIC Medical College and Post Graduate \\ Institute of Medical Sciences and Research, Rajajinagar, Bengaluru, India
}

\begin{abstract}
COVID-19 is an emerging viral disease affecting more than 200 countries worldwide and it present with varied clinical profile throughout the world. Without effective drugs to cure COVID-19, early identification and control of risk factors are important meas-
\end{abstract}

Correspondence: Dr. Yamini Marimuthu MD, Assistant Professor, Department of Community Medicine, ESIC Medical College and Post Graduate Institute of Medical Sciences and Research, Rajajinagar, Bengaluru 560010, India.

E-mail: yaminivaishnavidevi@gmail.com

Acknowledgements: We sincerely thank all front-line medical and paramedical staff for their hard work and sacrifice during this pandemic.

Contributions: All the authors made a substantive intellectual contribution. All the authors have read and approved the final version of the manuscript and agreed to be accountable for all aspects of the work.

Conflict of interest: The authors declare that they have no competing interests, and all authors confirm accuracy.

Ethical approval: The protocol was approved by the Institutional Ethical Committee. Since this a record-based study, informed consent is not applicable. Due permissions were taken from the concerned authorities for the conduct of the study. Data were collected anonymously and confidentiality was maintained throughout the study.

Availability of data and material: Available from the corresponding author on reasonable request.

Key words: COVID-19; SARS CoV-2; risk factors; survival analysis; mortality.

Received for publication: 8 December 2020.

Accepted for publication: 21 April 2021.

CCopyright: the Author(s), 2021

Licensee PAGEPress, Italy

Monaldi Archives for Chest Disease 2021; 91:1724

doi: 10.4081/monaldi.2021.1724

This article is distributed under the terms of the Creative Commons Attribution Noncommercial License (by-nc 4.0) which permits any noncommercial use, distribution, and reproduction in any medium, provided the original author(s) and source are credited. ures to combat COVID-19. This study was conducted to determine the clinical profile and risk factors associated with mortality among COVID-19 patients in a tertiary care hospital in South India. This record-based longitudinal study was conducted by reviewing the case records of COVID-19 patients admitted for treatment from June 2020 to September 2020 in a tertiary care centre in South India. The clinical details, discharge/death details, were collected and entered in MS Excel. Potential risk factors for COVID-19 mortality were analysed using univariate binomial logistic regression, generalized linear models (GLM) with Poisson distribution. Survival curves were made using the Kaplan-Meier method. Log-rank test was used to test the equality of survivor functions between the groups. Out of 854 COVID-19 patients, $56.6 \%$ were men and the mean (standard deviation) age was 45.3(17.2) years. The median survival time was significantly lesser in male COVID-19 patients (16 days) as compared to female patients (20 days). Increasing age, male gender, patients presenting with symptoms of fever, cough, breathlessness, smoking, alcohol consumption, comorbidities were significantly associated with mortality among COVID-19 patients. Patients with older age, male gender, breathlessness, fever, cough, smoking and alcohol and comorbidities need careful observation and early intervention. Public health campaigns aimed at reducing the prevalence of risk factors like diabetes, hypertension, smoking and alcohol use are also needed.

\section{Introduction}

Severe acute respiratory syndrome-related coronavirus-2 (SARS-CoV-2) infection emerged in Wuhan, China, and has spread rapidly worldwide [1]. Currently COVID-19 pandemic has affected $51,848,261$ cases and $1,280,868$ deaths till $10^{\text {th }}$ November 2020 [2]. India is currently burdened with $8,728,795$ cases and $1,28,668$ deaths as of $13^{\text {th }}$ November whereas Karnataka is affected with $8,55,912$ cases and 11,474 deaths [3]. The clinical presentation and the mortality pattern is widely varied across the countries. In countries like India with diversity, the presentation of COVID-19 is different even among different States.

Thirty percent of SARS-CoV-2 infection presents without any symptoms and usually recovers without immediate complications [4]. Evidence shows that $80 \%$ of the COVID-19 patients present with mild to moderate disease in which symptoms such as mild upper respiratory tract illness fever, cough, myalgia, fatigue, anosmia, breathlessness and pneumonia were present.[5] 
Around $20 \%$ of the COVID-19 patients present with severe acute respiratory illness and most of these severe patients succumb to death [5-7]. Severity of COVID-19 disease among patients infected with SARS-CoV-2 virus varies widely between different countries.

In Italy the proportion of severe cases was 37\% [8], in China it was $13.8 \%$ [9] and in the USA $12 \%$ of COVID-19 patients had severe cases. In India, most people with SARS CoV-2 infections develop mild or uncomplicated illnesses [5]. Only 14\% of the patients develop the severe disease that requires hospitalization and oxygen support, and 5\% require admission to an intensive care unit [5.] The risk factors for severe COVID-19 disease and mortality need to be identified to find out who are at higher risk of having severe disease and death.

Studies in other countries have identified that older age, male gender, presence of comorbidities like diabetes, hypertension, obesity, chronic kidney disease, smoking have positively associated with severity and mortality for COVID-19 [10-13]. Literature regarding risk factors for COVID-19 mortality is very limited in the Indian setting. Without effective drugs for COVID-19 and some vaccines which are under trial [14], the public health interventions like identification and control of risk factors, social distancing, wearing masks, performing hand hygiene remain the mainstay of management to combat COVID-19. For effective implementation of the above public interventions, early identification and management of risk factors for mortality due to COVID-19 is the need of the hour. With this background, this study was conducted to determine the risk factors associated with mortality among COVID-19 patients in a tertiary care hospital in South India.

\section{Methods}

A record-based longitudinal study was carried out by reviewing the case sheets of COVID-19 patients admitted for treatment in the tertiary care centre in Bengaluru. This tertiary care institution is equipped with around 500 beds and was designated as Dedicated COVID Health Centre (DCHC) in the last week of June 2020. Since then COVID-19 patients were given inpatient care in this institute. Standard care is being provided free of cost to COVID patients seeking care at the hospital as per the Ministry of Health and Family Welfare, Government of Karnataka guidelines.

Each COVID-19 patient's clinical details were maintained in the case records which were collected by the study investigators. The data related to the clinical and socio-demographic details were collected and entered in MS Excel. The data collected were anonymous and confidentiality of information was maintained throughout the study. A total of 854 case records of the confirmed COVID19 patients admitted from June 2020 to September 2020 were collected and analysed. Patients were followed till discharge or death from the hospital.

The variables collected from the case record and used for the analysis were age, gender, symptoms like fever, cough, breathlessness, sore throat, loose stools, chest pain, headache, myalgia, epidemiological details like the history of contact, history of travel to foreign countries, personal history like smoking, alcohol consumption, comorbidities like diabetes, hypertension, respiratory diseases, chronic kidney disease (CKD), malignancies, tuberculosis, hypothyroidism. The outcomes were classified into discharge from hospital, death of the COVID-19 patient. The continuous variable age is categorized in 10 years intervals.

\section{Operational definitions}

\section{History of contact}

A person who is involved in any works related to providing direct care without proper personal protective equipment for COVID-19 patients or staying in the same close environment of a COVID-19 patient in the last 14 days before the onset of symptoms [15].

\section{History of travel}

A person who has travelled to any foreign countries in the last 14 days before the onset of symptoms.

\section{History of smoking}

A person who is a current smoker or former smoker is considered as having a positive history of smoking [16].

\section{History of alcohol consumption}

Use of alcoholic beverages either on individual occasions (binge drinking) or as a regular practice is considered a positive history of alcohol consumption [17].

\section{Statistical analysis}

Data were entered using Microsoft Excel and analysis was done using STATA statistical software v. 14 (StataCorp LCC, College Station, TX, USA) [18]. The continuous variables age and duration of stay are summarized as mean with standard deviation (SD) or median with an interquartile range based on the distribution of data. The categorical variables are summarized as frequencies and proportions. Chi-square tests and Fischer's exact tests are used to test the statistical significance for the association of categorical data as appropriate. Univariate analysis was done using binomial logistic regression to identify the factors associated with mortality of COVID-19 patients. The strength of association is expressed as relative risk (RR) with $95 \%$ confidence interval $(95 \%$ $\mathrm{CI})$. The variables which were included in the multivariate regression model were selected based on the statistical significance of association $(\mathrm{p}<0.05)$ and clinical significance. Multivariate analysis was done using generalized linear models (GLM) with Poisson distribution to calculate adjusted relative risk (aRR) along with the $95 \%$ CI. A p-value less than 0.05 was considered statistically significant. Survival curves were made using the Kaplan-Meier method. Log-rank test was used to test the equality of survivor functions between the groups.

\section{Results}

A total of 854 COVID-19 patients were included in the study with a mean (SD) age of 45.3 (17.2) years. Among them, 371 (43.4\%) were women and 483 (56.6\%) were men. Symptoms with which the COVID-19 patients presented to the hospital were fever (48.24\%), cough (39.9\%), difficulty in breathing (29\%), myalgia $(21.9 \%)$, sore throat $(8.9 \%)$, headache $(8.7 \%)$, loose stools $(4 \%)$ and chest pain $(2.9 \%)$. The median (IQR) duration of stay in the hospital was 5 (3-8) days. The median survival time of COVID-19 patients in the hospital was 20 (95\% CI: 16-23) days. The median survival time was lesser in male COVID-19 patients (16 days) as 
compared to female patients (20 days) and the difference was statistically significant $(=0.054)$ (Figure 1$)$.

History of contact with positive COIVD-19 cases was present in $208(24.3 \%)$ patients and the history of travel to foreign countries was present in $126(14.7 \%)$ of the COVID-19 patients. History of smoking was there in $10(1.1 \%)$ and a history of alcohol consumption was present in $14(1.6 \%)$ of the COVID-19 patients. Out of the COVID-19 patients presented during the study period, $73(8.5 \%)$ were pregnant. Co-morbidity was present in 348 (40.7\%) of the COVID-19 patients presented to the hospital. The comorbidities with which they presented were hypertension (23.4\%), diabetes (23\%), hypothyroidism $(5.3 \%)$, chronic obstructive pulmonary disease $(1.5 \%)$, asthma $(1.4 \%)$, chronic kidney disease $(1.1 \%)$, cardiac illnesses $(4.3 \%)$, malignancy $(1.1 \%)$ and tuberculosis $(1.1 \%)$.

Our results have depicted that as the age increased, the risk of death due to COVID-19 also increased and the association was statistically significant. As compared to COVID-19 patients in the 3140-year age group, the patients in the 41-50 years age group had 1.4 (95\% CI: 0.6- 3.0) times increased risk of mortality (Table 1). Patients in the 51-60 years age group had 2.2 (95\% CI: 1.1-5.2) times increased risk of death, 61-70 years age group had $2.8(95 \%$ CI: $1.5-6.9)$ times increased risk of dying and 71-80 years age group had 3.4 (95\% CI: 1.7-9.8) times increased risk of dying. Male COVID-19 patients had 1.7 (95\% CI: 1.1-2.6) times increased risk of death as compared to female patients. COVID-19 patients who presented with fever had

2.0 (95\% CI: 1.3-3.1) times increased risk of mortality whereas patients who presented with cough had 1.4 (95\% CI: 0.94-2.1) times increased risk. Patients presented with breathlessness had 15.2 (95\% CI: 8.4-27.4) times increased risk of mortality as compared to patients without breathlessness symptoms (Figure 2). The symptoms like loose stools, chest pain, headache and myalgia were not significantly associated with mortality.

COVID-19 patients with a history of smoking had $6.2(95 \%$ CI: 3.6-10.8) times increased risk of death and patients with a history of alcohol consumption had 5.2 (95\% CI: 2.9-9.2) times increased risk of mortality (Table 2). COVID-19 patients with comorbidities had 4.0 (95\% CI: 2.5-6.3) times increased risk of death as compared to patients without comorbidities. These associations were statistically significant. Hypertension and diabetes were the common comorbidities with which COVID-19 patients presented to the hospital which increased the risk of mortality by 2.2 (95\% CI: 1.4-3.3) times and 4.0 (95\% CI: 2.7-5.9) times respectively. Respiratory comorbidities like COPD, Asthma and Tuberculosis increased the risk of mortality by 3.1 (95\% CI: $1.3-$ 7.3), 2.5 (95\% CI: 0.95-7.0) and 4.0 (95\% CI: 1.8-8.9) times respectively.

Other co-morbidities that significantly increased the risk of mortality in COVID-19 patients were CKD (RR=6.2 (95\% CI: 3.6$10.8)$ ) and cardiac illnesses $[\mathrm{RR}=3.5$ (95\% CI: 2.1-5.9)].

The variables included in the multivariate analysis were age, gender, presence of symptoms like fever, cough, breathlessness, history of smoking, history of alcohol consumption, presence of any comorbidity. In the multivariate analysis the variables age of the patient $(\mathrm{aRR}$ for $71-80$ years $=2.1(95 \% \mathrm{CI}: 1.1-4.4))$, presence of breathlessness during admission $(\mathrm{aRR}=10.6$ (95\% CI: 5.8 19.6)), and presence of any comorbidity ( $\mathrm{aRR}=1.9$ (95\% CI: $1.2-$ 3.1)) were significantly associated with mortality among COIVD19 patients admitted in the tertiary care centre.

\section{Discussion}

The results of our analysis have shown that increasing age, male gender, patients presenting with symptoms of fever, cough, breathlessness, smoking, alcohol consumption, presence of comorbidities like diabetes, hypertension, respiratory disease, chronic kidney disease, cardiac illness and malignancy were significantly associated with mortality among COVID-19 patients. A systematic review and meta-analysis done by Galbadage et al. have identified that male sex is a significant risk factor for severe disease and COVID-19 mortality [19]. The immunological, biological, cultural

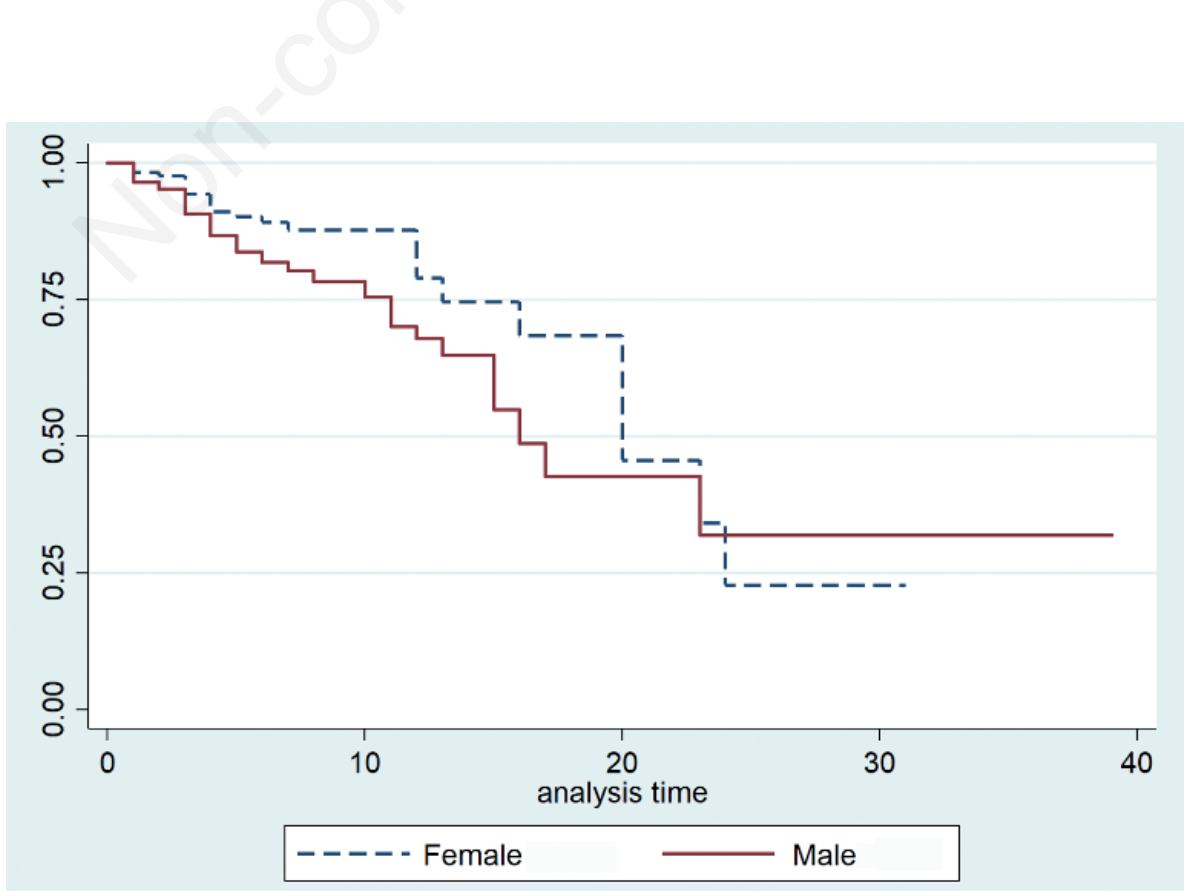

Figure 1. Kaplan-Meier survival estimates. 
Table 1. Association of demographic and clinical characteristics with mortality among COVID-19 patients admitted to the tertiary care centre $(n=854)$.

\begin{tabular}{|c|c|c|c|c|c|c|}
\hline Characteristics & Categories & $\begin{array}{c}\text { Discharged } \\
(n=767) \\
\text { Frequency }(\%)\end{array}$ & $\begin{array}{c}\text { Died } \\
(\mathrm{n}=87) \\
\text { Frequency }(\%)\end{array}$ & $\begin{array}{c}\text { RR } \\
(95 \% \mathrm{CI}) *\end{array}$ & $\begin{array}{c}\text { aRR } \\
(95 \% \mathrm{CI})^{\circ}\end{array}$ & p-value \\
\hline Age & $\begin{array}{c}0-10 \\
11-20 \\
21-30 \\
31-40 \\
41-50 \\
51-60 \\
61-70 \\
71-80 \\
81-90\end{array}$ & $\begin{array}{c}14(100 \%) \\
31(100 \%) \\
151(98.7 \%) \\
153(93.3 \%) \\
140(90.3 \%) \\
130(84.9 \%) \\
99(81.1 \%) \\
41(77.3 \%) \\
8(88.9 \%)\end{array}$ & $\begin{array}{c}0(0.0 \%) \\
0(0.0 \%) \\
2(1.3 \%) \\
11(6.7 \%) \\
15(9.7 \%) \\
23(15.1 \%) \\
23(18.9 \%) \\
12(22.7 \%) \\
1(11.1 \%)\end{array}$ & $\begin{array}{c}- \\
- \\
0.2(0.04-0.84) \\
1 \\
1.4(0.6-3.0) \\
2.2(1.1-5.2) \\
2.8(1.5-6.9) \\
3.4(1.7-9.8) \\
1.6(0.19-15.1)\end{array}$ & $\begin{array}{c}0.41(0.09-1.7) \\
1 \\
1.0(0.49-2.0) \\
1.2(0.63-2.2) \\
1.4(0.73-2.7) \\
2.1(1.1-4.4) \\
1.2(0.54-2.8)\end{array}$ & $\begin{array}{l}0.030 \\
\\
0.336 \\
0.021 \\
0.003 \\
0.002 \\
0.609\end{array}$ \\
\hline Sex & $\begin{array}{l}\text { Female } \\
\text { Male }\end{array}$ & $\begin{array}{l}344(92.7 \%) \\
423(87.6 \%)\end{array}$ & $\begin{array}{l}27(7.3 \%) \\
60(12.4 \%)\end{array}$ & $\begin{array}{c}1 \\
1.7(1.1-2.6)\end{array}$ & $1.1(0.77-1.7)$ & 0.016 \\
\hline Fever & $\begin{array}{l}\text { No } \\
\text { Yes }\end{array}$ & $\begin{array}{l}412(93.2 \%) \\
355(86.2 \%)\end{array}$ & $\begin{array}{c}30(6.8 \%) \\
57(13.8 \%)\end{array}$ & $\begin{array}{c}1 \\
2.0(1.3-3.1)\end{array}$ & $\begin{array}{c}1 \\
1.3(0.91-2.0)\end{array}$ & 0.001 \\
\hline Cough & $\begin{array}{l}\text { No } \\
\text { Yes }\end{array}$ & $\begin{array}{l}468(91.2 \%) \\
299(87.7 \%)\end{array}$ & $\begin{array}{c}45(8.8 \%) \\
42(12.3 \%)\end{array}$ & $\begin{array}{c}1 \\
1.4(0.94-2.1)\end{array}$ & $0.67(0.46-0.97)$ & 0.094 \\
\hline Breathlessness & $\begin{array}{l}\text { No } \\
\text { Yes }\end{array}$ & $\begin{array}{l}593(98.0 \%) \\
174(69.9 \%)\end{array}$ & $\begin{array}{c}12(2.0 \%) \\
75(30.1 \%)\end{array}$ & $\begin{array}{c}1 \\
15.2(8.4-27.4)\end{array}$ & $\begin{array}{c}1 \\
10.6(5.8-19.6)\end{array}$ & $<0.001$ \\
\hline Loose stools & $\begin{array}{l}\text { No } \\
\text { Yes }\end{array}$ & $\begin{array}{l}736(89.9 \%) \\
31(88.6 \%)\end{array}$ & $\begin{array}{c}83(10.1 \%) \\
4(11.4 \%)\end{array}$ & $\begin{array}{c}1 \\
1.1(0.43-2.9)\end{array}$ & $\begin{array}{l}- \\
-\end{array}$ & 0.803 \\
\hline Chest pain & $\begin{array}{l}\text { No } \\
\text { Yes }\end{array}$ & $\begin{array}{c}747(90.1 \%) \\
20(80 \%)\end{array}$ & $\begin{array}{c}82(9.9 \%) \\
5(20 \%)\end{array}$ & $\begin{array}{c}1 \\
2.0(0.89-4.5)\end{array}$ & - & 0.189 \\
\hline Headache & $\begin{array}{l}\text { No } \\
\text { Yes }\end{array}$ & $\begin{array}{c}696(89.3 \%) \\
71(94.7 \%)\end{array}$ & $\begin{array}{c}83(10.7 \%) \\
4(5.3 \%)\end{array}$ & $\begin{array}{c}1 \\
0.50(0.18-1.3)\end{array}$ & - & 0.164 \\
\hline Myalgia & $\begin{array}{l}\text { No } \\
\text { Yes }\end{array}$ & $\begin{array}{l}599(89.8 \%) \\
168(89.8 \%)\end{array}$ & $\begin{array}{l}68(10.2 \%) \\
19(10.2 \%)\end{array}$ & $\begin{array}{c}1 \\
0.99(0.61-1.61)\end{array}$ & $\begin{array}{l}- \\
-\end{array}$ & 0.989 \\
\hline Sore throat & $\begin{array}{l}\text { No } \\
\text { Yes }\end{array}$ & $\begin{array}{l}691(88.8 \%) \\
76(100 \%)\end{array}$ & $\begin{array}{c}87(11.2 \%) \\
0(0.0 \%)\end{array}$ & $\begin{array}{l}- \\
-\end{array}$ & - & $\begin{array}{l}- \\
-\end{array}$ \\
\hline
\end{tabular}

*RR, relative risk; ${ }^{\circ} \mathrm{aRR}$, adjusted relative risk.

Table 2. Association of epidemiologic and clinical characteristics with mortality among COVID-19 patients admitted to the tertiary care centre $(n=854)$.

\begin{tabular}{|c|c|c|c|c|c|c|}
\hline Factor & Categories & Discharge & Death & $\operatorname{RR}(95 \% \mathrm{CI}) *$ & $\operatorname{aRR}(95 \% \mathrm{CI})^{\circ}$ & p-value \\
\hline History of contact & $\begin{array}{l}\text { No } \\
\text { Yes }\end{array}$ & $\begin{array}{l}564(87.3 \%) \\
203(97.6 \%)\end{array}$ & $\begin{array}{c}82(12.7 \%) \\
5(2.4 \%)\end{array}$ & $\begin{array}{c}1 \\
0.18(0.07-0.46)\end{array}$ & $\begin{array}{l}- \\
-\end{array}$ & $<0.001$ \\
\hline History of travel & $\begin{array}{l}\text { No } \\
\text { Yes }\end{array}$ & $\begin{array}{l}643(88.3 \%) \\
124(98.4 \%)\end{array}$ & $\begin{array}{c}85(11.7 \%) \\
2(1.6 \%)\end{array}$ & $\begin{array}{c}1 \\
0.13(0.03-0.54)\end{array}$ & - & 0.005 \\
\hline History of smoking & $\begin{array}{l}\text { No } \\
\text { Yes }\end{array}$ & $\begin{array}{c}763(90.4 \%) \\
4(40 \%)\end{array}$ & $\begin{array}{c}81(9.6 \%) \\
6(60 \%)\end{array}$ & $\begin{array}{c}1 \\
6.2(3.6-10.8)\end{array}$ & $\begin{array}{c}1 \\
1.4(0.56-3.6)\end{array}$ & $<0.001$ \\
\hline History of alcoholconsumption & $\begin{array}{l}\text { No } \\
\text { Yes }\end{array}$ & $\begin{array}{l}760(90.5 \%) \\
7(50 \%)\end{array}$ & $\begin{array}{c}80(9.5 \%) \\
7(50 \%)\end{array}$ & $\begin{array}{c}1 \\
5.2(2.9-9.2)\end{array}$ & $\begin{array}{c}1 \\
1.3(0.51-3.5)\end{array}$ & $<0.001$ \\
\hline Pregnancy & $\begin{array}{l}\text { No } \\
\text { Yes }\end{array}$ & $\begin{array}{l}694(88.9 \%) \\
73(100 \%)\end{array}$ & $\begin{array}{c}87(11.1 \%) \\
0(0.0 \%)\end{array}$ & $\begin{array}{l}- \\
-\end{array}$ & $\begin{array}{l}- \\
-\end{array}$ & $\begin{array}{l}- \\
-\end{array}$ \\
\hline Co-morbidity & $\begin{array}{l}\text { No } \\
\text { Yes }\end{array}$ & $\begin{array}{l}483(95.5 \%) \\
284(81.6 \%)\end{array}$ & $\begin{array}{l}23(4.5 \%) \\
64(18.4 \%)\end{array}$ & $\begin{array}{c}1 \\
4.0(2.5-6.3)\end{array}$ & $\begin{array}{c}1 \\
1.9(1.2-3.1)\end{array}$ & $<0.001$ \\
\hline Hypertension & $\begin{array}{l}\text { No } \\
\text { Yes }\end{array}$ & $\begin{array}{l}602(92.1 \%) \\
163(82.5 \%)\end{array}$ & $\begin{array}{c}52(7.9 \%) \\
35(17.5 \%)\end{array}$ & $\begin{array}{c}1 \\
2.2(1.4-3.2)\end{array}$ & $\begin{array}{l}- \\
-\end{array}$ & $<0.001$ \\
\hline Diabetes & $\begin{array}{l}\text { No } \\
\text { Yes }\end{array}$ & $\begin{array}{l}615(94.0 \%) \\
152(76.0 \%)\end{array}$ & $\begin{array}{c}39(6.0 \%) \\
48(24.0 \%)\end{array}$ & $\begin{array}{c}1 \\
4.0(2.7-5.9)\end{array}$ & - & $<0.001$ \\
\hline Respiratory disease & $\begin{array}{c}\text { No } \\
\text { COPD } \\
\text { Asthma }\end{array}$ & $\begin{array}{c}749(90.3 \%) \\
9(69.2 \%) \\
9(75.0 \%)\end{array}$ & $\begin{array}{l}80(9.6 \%) \\
4(30.8 \%) \\
3(25.0 \%)\end{array}$ & $\begin{array}{c}1 \\
3.1(1.3-7.3) \\
2.5(0.95-7.0)\end{array}$ & $\begin{array}{l}- \\
- \\
-\end{array}$ & $\begin{array}{l}0.007 \\
0.063\end{array}$ \\
\hline Tuberculosis & $\begin{array}{l}\text { No } \\
\text { Yes }\end{array}$ & $\begin{array}{c}761(90.2 \%) \\
6(60.0 \%)\end{array}$ & $\begin{array}{l}83(9.8 \%) \\
4(40.0 \%)\end{array}$ & $\begin{array}{c}1 \\
4.0(1.8-8.9)\end{array}$ & $\begin{array}{l}- \\
-\end{array}$ & $<0.001$ \\
\hline Chronic kidney disease & $\begin{array}{l}\text { No } \\
\text { Yes }\end{array}$ & $\begin{array}{c}763(90.4 \%) \\
4(40.0 \%)\end{array}$ & $\begin{array}{l}81(9.6 \%) \\
6(60.0 \%)\end{array}$ & $\begin{array}{c}1 \\
6.2(3.6-10.8)\end{array}$ & - & $<0.001$ \\
\hline Cardiac illnesses & $\begin{array}{l}\text { No } \\
\text { Yes }\end{array}$ & $\begin{array}{l}742(90.8 \%) \\
25(67.6 \%)\end{array}$ & $\begin{array}{c}75(9.2 \%) \\
12(32.4 \%)\end{array}$ & $\begin{array}{c}1 \\
3.5(2.1-5.9)\end{array}$ & $\begin{array}{l}- \\
-\end{array}$ & $<0.001$ \\
\hline Malignancy & $\begin{array}{l}\text { No } \\
\text { Yes }\end{array}$ & $\begin{array}{c}759(89.9 \%) \\
8(80.0 \%)\end{array}$ & $\begin{array}{c}85(10.1 \%) \\
2(20.0 \%)\end{array}$ & $\begin{array}{c}1 \\
1.9(0.56-6.9)\end{array}$ & - & 0.284 \\
\hline Hypothyroidism & $\begin{array}{l}\text { No } \\
\text { Yes }\end{array}$ & $\begin{array}{c}725(89.6 \%) \\
42(93.3 \%)\end{array}$ & $\begin{array}{c}84(10.4 \%) \\
3(6.7 \%)\end{array}$ & $0.64(0.2-1.9)$ & $\begin{array}{l}- \\
-\end{array}$ & 0.435 \\
\hline
\end{tabular}

${ }^{*} \mathrm{RR}$, relative risk; ${ }^{\circ} \mathrm{aRR}$ - adjusted relative risk; COPD, chronic obstructive pulmonary disease. 
and socio-behavioural aspects might have led to the unfavourable situation for the male sex [20,21].

Our study depicted that older age increased the risk of COVID19 mortality in the Indian population which was similar to other studies in the Mexican and Chinese populations [10,11,17]. Agerelated decrease in clearance of inhaled particles in the airway, immunosenescence (a gradual decline in immune function due to aging), the change in quantity and quality of mucins and protective glycoproteins found in mucosal barriers, presence of comorbidities might be the reasons for the increased risk of COVID-19 mortality among older individuals [22,23].

Smoking and alcohol are significantly associated with COVID-19 mortality in our study which is similar to the results from other studies $[10,11]$. The reasons for increased mortality among patients with alcohol consumption might be immunological changes, malnutrition, alcohol- related liver diseases and changes in the amount of Angiotensin-converting enzyme 2 [24], which is a target enzyme for SARS-CoV-2 [25]. Increased COVID-19 mor- tality among smokers might be due to the detrimental action of tobacco smoke on the immune system, direct lung injury, up-regulation of SARS-CoV-2 receptor, Angiotensin-converting enzyme 2 (ACE2) in human cells [26] due to smoking [25].

Among the various symptoms for COVID-19 disease, our study identified that the presence of fever, cough and breathlessness are significantly associated with COVID-19 mortality. Other studies done in China and Nigeria also showed that these symptoms are associated with severe disease and mortality due to COVID-19 [27-29]. In the study done in Nigeria, breathlessness increased the risk of mortality by 19 times (OR=19.26 95\% CI 10.95-33.88) which is similar to our study [27]. The presence of any comorbidity increased the risk of death by 4 times in our study, which is similar to other studies [11,27,29]. With diabetes and hypertension are the most common co-morbidities among COVID19 patients in India, ACE2 mediated pathway, abnormal blood glucose levels mediated disruption of immunity might be the reasons for increased mortality among COVID-19 patients [30]. The pres-

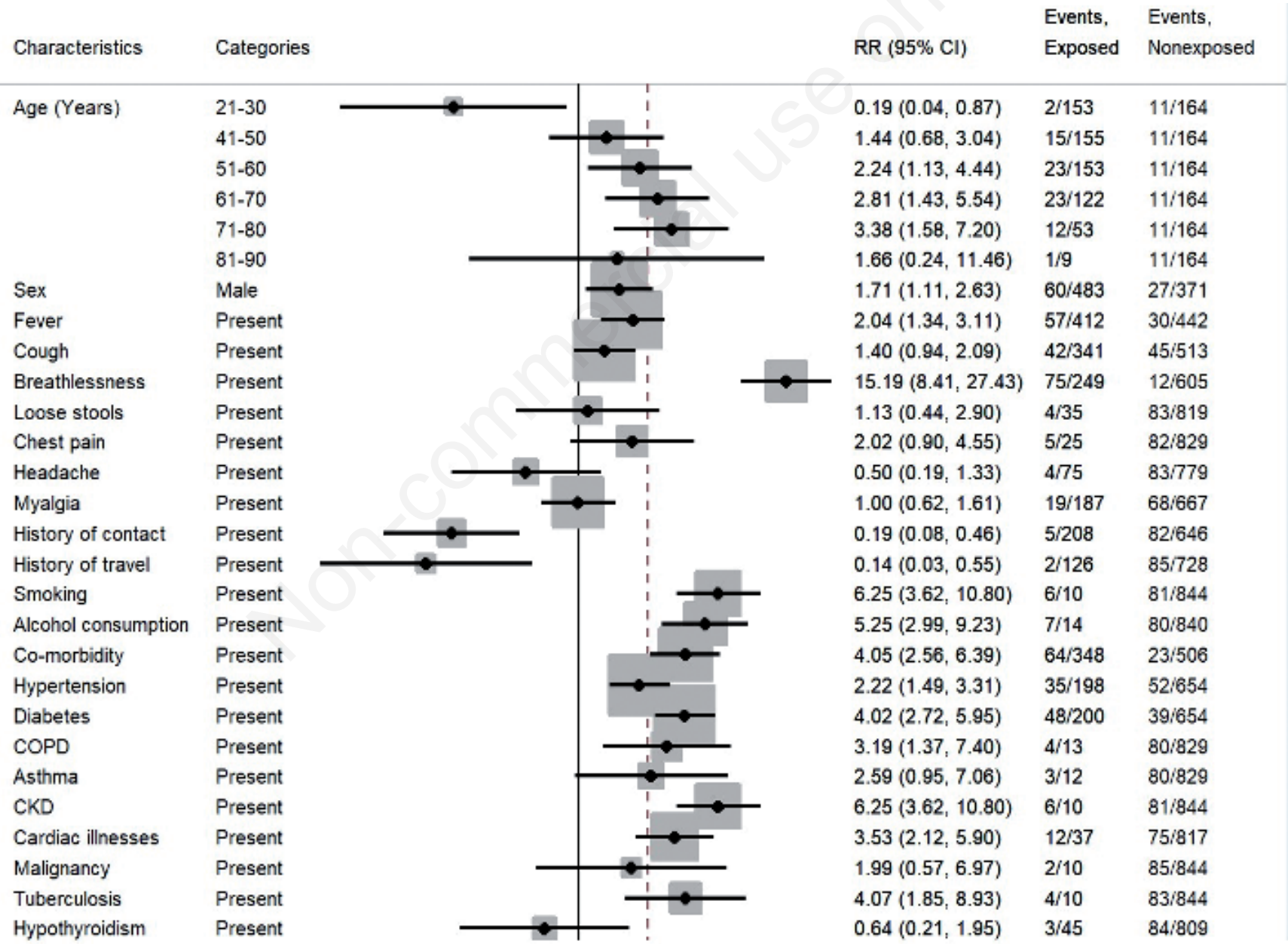

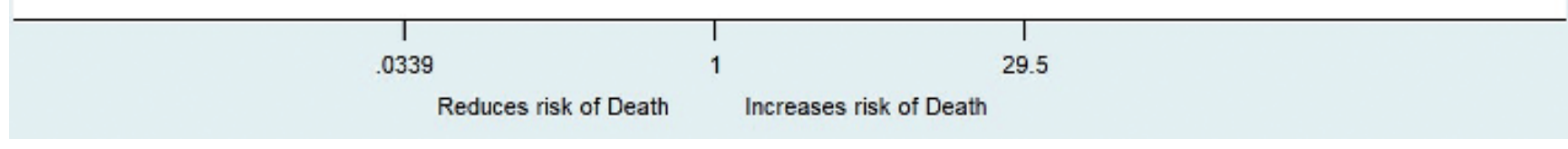

Figure 2. Forest plot of univariate analysis of risk factors associated with COVID-19 mortality. 
ence of other co-morbidities like obesity in diabetes and hypertension might also be contributing to the mortality by altered immune responses due to low vitamin D levels and adiponectin levels and high leptin levels [30,31]. Our analysis also identified 6 times increased risk of COVID-19 mortality among CKD patients. SARS-CoV-2 might affect the kidney through the ACE2-dependent pathway, causing acute renal impairment and death [32].

\section{Strengths and limitations}

Our study analyzed the data from a large number of COVID19 patients. The results of the study are comparable to the literature on risk factors for COVID-19 mortality from India and other countries. Since this is a record-based study from a tertiary health care center, the generalizability of the results needs to be done with caution. This study represents the findings from a dynamic and rapidly changing pandemic for which the evidence may change over time. Nevertheless, our study provides valuable evidence on the symptom profile and risk factors for COVID-19 mortality from India.

\section{Conclusions}

To conclude, increasing age, male gender, presenting symptoms like fever, cough, breathlessness, smoking, alcohol consumption, presence of comorbidities were identified as the significant risk factors for mortality due to COVID-19. Early identification of these risk factors and appropriate treatment is important to prevent death among COVID-19 patients. It is recommended that COVID-19 patients with these risk factors can be given appropriate inpatient care instead of domiciliary management to prevent fatal outcomes among high-risk patients. We also need to implement public health campaigns aimed at reducing the prevalence of risk factors like diabetes, hypertension, smoking and alcohol use and other comorbidities. Long term consequences of COVID-19 disease need to be assessed with longitudinal studies with longer follow up period.

\section{References}

1. World Health Organization. WHO Timeline - COVID-19. 2020. Available from: https://www.who.int/news-room/detail/08-042020-who-timeline---covid-19

2. World Health Organization. Weekly epidemiological update 10 November 2020. Available from: https://www.who.int/publications/m/item/weekly-epidemiological-update---10-november-2020

3. Ministry of Health and Family Welfare. COVID-19 India. Gov. India. 2020. Available from: https://www.mohfw.gov.in/

4. Nishiura H, Kobayashi T, Suzuki A, et al. Estimation of the asymptomatic ratio of novel coronavirus infections (COVID19). Int J Infect Dis 2020;94:154-5.

5. Adhikari SP, Meng S, Wu Y-J, et al. Epidemiology, causes, clinical manifestation and diagnosis, prevention and control of coronavirus disease (COVID-19) during the early outbreak period: a scoping review. Infect Dis Poverty 2020;9:29.

6. Chen N, Zhou M, Dong X, et al. Epidemiological and clinical characteristics of 99 cases of 2019 novel coronavirus pneumonia in Wuhan, China: a descriptive study. Lancet 2020;395:507-13.

7. Wang D, Hu B, Hu C, et al. Clinical characteristics of 138 hospitalized patients with 2019 novel coronavirus-infected pneumonia in Wuhan, China. JAMA 2020;323:1061-9.

8. Colaneri M, Sacchi P, Zuccaro V, et al. Clinical characteristics of coronavirus disease (COVID-19) early findings from a teaching hospital in Pavia, North Italy, 21 to 28 February 2020. Euro Surveill 2020;25:2000460.

9. Chen J, Lu H, Melino G, et al. COVID-19 infection: the China and Italy perspectives. Cell Death Dis 2020;11:1-17.

10. Salinas-Escudero G, Carrillo-Vega MF, Granados-García V, et al. A survival analysis of COVID-19 in the Mexican population. BMC Public Health 2020;20:1616.

11. Li X, Xu S, Yu M, et al. Risk factors for severity and mortality in adult COVID-19 inpatients in Wuhan. J Allergy Clin Immunol 2020;146:110-8.

12. Chen L, Zhang B, Ti M, et al. Clinical course of severe and critically ill patients with coronavirus disease 2019 (COVID19): A comparative study. J Infect 2020;81:e82-4.

13. Zheng Z, Peng F, Xu B, et al. Risk factors of critical and mortal COVID-19 cases: A systematic literature review and metaanalysis. J Infect 2020;81:e16-25.

14. National Institutes of Health [Internet]. Phase 3 clinical trial of investigational vaccine for COVID-19 begins. 2020. Available from: https://www.nih.gov/news-events/news-releases/phase3-clinical-trial-investigational-vaccine-covid-19-begins

15. National Centre for Disease Control [Internet]. The updated case definitions and contact-categorisation. New Delhi: 2020. Available from: https://ncdc.gov.in/WriteReadData/1892s/ 89568514191583491940.pdf

16. World Health Organization. Global Adult Tobacco Survey (GATS) Indicator Guidelines: Definition and Syntax. 2009. Available from: https://www.who.int/tobacco/surveillance/en tfi_gats_indicator_guidelines.pdf

17. Song $\mathrm{J}, \mathrm{Hu} \mathrm{W}, \mathrm{Yu} \mathrm{Y}$, et al. A comparison of clinical characteristics and outcomes in elderly and younger patients with covid19. Med Sci Monit 2020;26:e925047.

18. StataCorp. Stata Statistical Software: Release 14. 2017.

19. Galbadage T, Peterson BM, Awada J, et al. Systematic review and meta-analysis of sex-specific COVID-19 clinical outcomes. Front Med 2020;7:348.

20. Maleki Dana P, Sadoughi F, Hallajzadeh J, et al. An Insight into the sex differences in COVID-19 patients: What are the possible causes? Prehosp Disaster Med 2020;35:438-41.

21. Salvati L, Biagioni B, Vivarelli E, Parronchi P. A gendered magnifying glass on COVID-19. Clin Mol Allergy 2020;18:14.

22. Mueller AL, Mcnamara MS, Sinclair DA. Why does COVID19 disproportionately affect older people? Aging (Albany NY) 2020;12:9959-81.

23. Perrotta F, Corbi G, Mazzeo G, et al. COVID-19 and the elderly: insights into pathogenesis and clinical decision-making. Aging Clin Exp Res 2020;32:1599-608.

24. Okuno F, Arai M, Ishii H, et al. Mild but prolonged elevation of serum angiotensin converting enzyme (ACE) activity in alcoholics. Alcohol 1986;3:357-9.

25. Mallet J, Dubertret C, Le Strat Y. Addictions in the COVID-19 era: Current evidence, future perspectives a comprehensive review. Prog Neuro-Psychopharmacology Biol Psychiatry 2021;160:110070.

26. Cai G, Bossé Y, Xiao F, Kheradmand F, Amos CI. Tobacco smoking increases the lung gene expression of ACE2, the Receptor of SARS-CoV-2. Am J Respir Crit Care Med 2020;201:1557-9. 
27. Abayomi A, Odukoya O, Osibogun A, et al. Presenting symptoms and predictors of poor outcomes among 2,184 patients with COVID-19 in Lagos State, Nigeria. Int J Infect Dis 2020;102: 226-32.

28. Li L, Sun W, Han M, et al. A study on the predictors of disease severity of COVID-19. Med Sci Monit 2020;26:8.

29. Jain V, Yuan J-M. Predictive symptoms and comorbidities for severe COVID-19 and intensive care unit admission: a systemat- ic review and meta-analysis. Int J Public Health 2020;65:533-46.

30. Apicella M, Campopiano MC, Mantuano M, et al. COVID-19 in people with diabetes: understanding the reasons for worse outcomes. Lancet Diabetes Endocrinol 2020;8:782-92.

31. Mitchell F. Vitamin-D and COVID-19: do deficient risk a poorer outcome? Lancet Diabetes Endocrinol 2020;8:570.

32. Ajaimy M, Melamed ML. Covid-19 in patients with kidney disease. Clin J Am Soc Nephrol 2020;15:1087-9. 